\title{
Benchmarking Graduate School Development Practices
}

Received (in revised form): July 14, 2005

\section{Michael C. Poock}

Dr. Michael C. Poock is an associate professor in the doctoral program in educational leadership at East Carolina University in Greenville, North Carolina. He holds a Ph.D. in higher education administration and master's degrees in public administration and mass communication. His research interests are graduate education, enrollment management, and the application of web technologies.

\section{David J. Siegel}

Dr. David J. Siegel is associate professor of educational leadership at East Carolina University, where he teaches courses in policy, planning, and organization theory. His research focuses on issues of diversity and academicindustry nonprofit partnerships, and he has professional experience in major gifts and corporate and foundation relations. He earned his Ph.D. in higher education from the University of Michigan.

\begin{abstract}
There is little empirical evidence documenting the development activities of academic units in colleges and universities. This study attempts to bridge the knowledge gap by examining the development practices of graduate schools, which confront special challenges in their efforts to generate private support. Results from a survey of member institutions of the Council of Graduate Schools (CGS) are reported and discussed. This field-level perspective should provide scholars with a better understanding of the everexpanding development practices at academic institutions while assisting graduate school administrators or other
\end{abstract}

Author's Contact Address:

Michael C. Poock

Associate Professor

307 Speight Building

East Carolina University

Greenville, NC 27858, USA

Phone: +1 919 949-7457

Email: poockm@mail.ecu.edu unit leaders interested in a comparative context for their development efforts. Keywords:

development, fund raising, graduate school

\section{Introduction}

Financing higher education has long been a concern of campus leaders, policy makers, and scholars. Private support is no exception, given that it is a growing source of revenue for colleges and universities at a time when state appropriations and other public funding are on the wane. ${ }^{1}$ According to the Council for Aid to Education, ${ }^{2} \$ 24.4 \mathrm{bn}$ in private support flowed to higher education in 2004. Sources of charitable giving during this period included alumni ( $\$ 6.7 \mathrm{bn})$, other individuals ( $\$ 5.2 \mathrm{bn})$, corporations $(\$ 4.4 \mathrm{bn})$, foundations $(\$ 6.2 \mathrm{bn})$, religious organizations $(\$ 350 \mathrm{~m})$, and other organizations $(\$ 1.55 \mathrm{bn})$. Billiondollar campaigns are now common among research universities, and several of these (including public institutions such as Michigan, Virginia, and UCLA) are 
engaged in multibillion dollar campaigns. ${ }^{3}$

This enormous transfer of private wealth to institutions of higher education is the raison d'être of development offices, which have experienced their own significant growth in response to expanding institutional priorities, needs, and appetites. ${ }^{4}$ Development has become an essential part of the weave and fabric of the academy; indeed, some observers speculate that the "regularization" of fund development practices will make the venerable capital campaign, with its punctuated burst of activity, nearly obsolete in the 21 st century. ${ }^{5}$

One significant measure of the institutionalization of development is its sheer proliferation on most campuses; there is a clear trend toward decentralization in which academic units perform more of the essential development functions historically handled by centralized development offices. In this formulation, deans are expected to play an increasingly pivotal role in garnering private dollars, ${ }^{6}$ similar to the one played by college and university presidents at the institutional level.

This expectation is particularly pronounced on the professional school front, although the pressure to generate private support is felt by academic deans across campus. Miller, ${ }^{7}$ for example, has likened the role of law school deans to that of professional fund raiser, with more and more of a dean's time and effort devoted to development activities. Additionally, many business school deans now preside over campaigns of several hundred million dollars, and their active leadership role in these efforts is a required component of the job. ${ }^{8}$

Perhaps the greatest challenge in this regard is for deans of graduate schools who have no clear constituency. Such deans support graduate education as a whole but do not represent any single discipline. However, fund raising by graduate deans is increasingly important and certainly not a new discussion in the field. The Council of Graduate Schools (CGS), the professional organization for graduate deans, has addressed the critical nature of fund raising for years. At the 1987 annual meeting of CGS, for example, Gordon emphasized the necessity of deans undertaking development activities that support graduate education. ${ }^{9}$ This theme was echoed, in part, by Rosenzweig at the following CGS annual meeting in $1988 .^{10}$

The call to greater engagement in development activities by graduate deans is clear, particularly amid intensifying competition for faculty and students. To date, however, little has been written about development in the graduate school setting that might be of use to leaders in planning, executing, and comparing their fund-raising strategies. The overarching purpose of this study is to bridge this gap by benchmarking current development practices among graduate schools throughout the United States.

\section{Background}

While development operations have grown in scope, complexity, and sophistication over time, ${ }^{11}$ empirical and theoretical insights have not kept pace. As Kelly has noted, development tends to be guided by "practitioner wisdom and time-tested principles."12 The need for more (and more rigorous) research has been a major topic of discussion among professional fund raisers for many years. As far back as 1985, the Council for the Advancement and Support of Education (CASE) indicated that this knowledge base was critical to the growth of the advancement field. Development literature since that 
time has looked at the presidential role in fund raising, ${ }^{13}$ philanthropic motivations, ${ }^{14}$ professionalization, ${ }^{15}$ centralization and decentralization of university development offices, ${ }^{16}$ effectiveness and productivity, ${ }_{17}^{17}$ and various aspects of organizing. ${ }^{18}$

Many important questions and issues remain to be investigated, and their timing could not be more crucial for higher education. The combination of spiraling labor costs, facilities upgrades, advanced technologies, and competition from new undergraduate and graduate education providers, ${ }^{19}$ presents a daunting funding imperative. As Clark has suggested, ${ }^{20}$ private support (or "thirdstream" income) from industrial firms, philanthropic foundations, and alumni effectively functions as the venture capital that allows institutions and their units to become more entrepreneurial in the face of increasing stakeholder demands. The status of graduate schools in the fund raising firmament may take on added significance as concerns mount about how the balance of unit power within institutions shifts with the "privatization" of the academy. ${ }^{21}$

\section{Methodology}

\section{Participants}

All 438 member institutions of CGS were contacted for this study. In instances where an institution had multiple administrators who held membership in this organization, the highest ranking individual was contacted. Individuals were sent personalized emails requesting their participation and directing them to an online questionnaire. Approximately three weeks later a follow-up email message was sent to those who had not responded.

\section{Research instrument}

The questionnaire was developed by reviewing the literature and consulting with development professionals in higher education. Once the questionnaire was developed, it was pilot tested with a dozen development professionals representing a range of institutional types by Carnegie Classification. After final revisions to the questionnaire, the email request for participation was sent in early 2005 .

\section{Results}

Of the 438 initial email messages sent, 58 were returned as undeliverable. This resulted in a total of 380 possible respondents. A total of 75 people completed the questionnaire, yielding a response rate of 20 percent.

Of those who participated, 15 percent were from extensive and 44 percent were from intensive doctoral/research universities. Thirty-six percent were from masters I institutions, 4 percent from masters II institutions, and 1 percent from baccalaureate colleges-liberal arts.

The amount of each respondent's annual budget varied greatly, from $\$ 350$ to $\$ 19 \mathrm{~m}$. In these budgets, 8 percent of respondents' offices received no revenue from state appropriations, 21 percent received up to 75 percent of their revenue from the state, and 21 percent received in excess of three-quarters of their budget from this source.

Five percent indicated they received no revenue from tuition. The revenue from tuition for the remaining respondents varied widely, ranging from 10 to 98 percent. Eleven percent of the respondents received no revenue from private funds, and 66 percent received up to 10 percent of their revenue from this source. Just 8 percent obtained more than 10 percent of their revenue from private funds. Nine percent of the respondents received no 
revenue from endowments. Indeed, just under one-quarter received any funds at all from this source, ranging from 1 to 30 percent of their total revenue.

Approximately half of the respondents were engaged in development activities. Moreover, only 15 of the 75 respondents indicated that they employed a person responsible for coordinating such activities. Five institutions employed an assistant or associate dean for these duties, although none were dedicated full-time for these efforts (four dedicated 25 percent of their time toward development and one dedicated 50 percent). Five respondents employed a director of development who worked full time. Four other respondents also employed a director, although these individuals dedicated just 25 to 50 percent of their time for graduate school development efforts. Eight respondents employed a coordinator in this capacity, with one devoted full-time to development, six devoting 50 percent of their time, and one devoting just 25 percent of their time.

The number of employees who worked less than full time for graduate school development activities may be due to sharing the cost and time with the central development office on their respective campuses. Five respondents shared the cost of the individuals who carried the title of coordinator, with one being paid completely by the central office and four having half of their salary paid by the central office.

Although the aforementioned individuals assisted with development activities, it appeared that the dean of the graduate school was the chief fund raiser. Thirty-one percent of the respondents indicated that the dean dedicated at least 10 percent of his or her time to development. Twenty-three percent of the deans dedicated between 20 and 30 percent of their time for development.
The majority of the deans began their development efforts fairly recently. Eightythree percent of the respondents indicated that their office initiated development activities between 2000 and 2004 . Additionally, 34 percent of the deans engaged in these efforts without the support of an advancement board. Seven percent enjoyed the support of a board composed of individuals not employed by the institution. Four percent utilized a board that was a mix of employees and nonemployees, and just 1 percent had an all-employee board. Only 10 respondents indicated how their advancement board was selected, and these methods varied from being selected by the university president, the dean, or the central development office.

The variety in how boards were selected paralleled the differences in amount of total dollars raised since development activities were initiated. With no consistency in responses, fund-raising totals ranged from under $\$ 5000$ to $\$ 20 \mathrm{~m}$. There was also no consistency in amount of funds raised specifically in fiscal year 2003. Amounts varied from "don't know" to several million dollars.

Approximately one quarter of the respondents $(24 \%)$ were participating in their institution's capital campaign, with graduate school goals ranging from $\$ 100,000$ to $\$ 18 \mathrm{~m}$. In comparison, respondents' institutional capital campaign goals ranged from $\$ 10 \mathrm{~m}$ to $\$ 1.8$ bn.

With the private funds raised, 37 percent of respondents used some or all of these monies for assistantships and/or fellowships for graduate students. The distribution of these monies is provided in Table 1. Clearly, the largest number of respondents offered up to 10 assistantships/fellowships per year, with a value up to $\$ 20,000$. The number of 
Table 1: Number and amount of assistantships/fellowships and supplemental funds*

\begin{tabular}{|c|c|c|c|c|}
\hline \#Offered & $n$ & $\begin{array}{l}\text { Assist/Fellow } \\
\text { Range \$ }\end{array}$ & $n$ & $\begin{array}{l}\text { Supplemental } \\
\text { Range \$ }\end{array}$ \\
\hline $0-10$ & 13 & $1000-20,000+$ & 10 & $1001-6000$ \\
\hline $11-20$ & 4 & $4001-7,000$ & 3 & $2001-6000$ \\
\hline $31-40$ & 2 & $1000-\$ 15,000$ & - & - \\
\hline $41-50$ & 1 & $15,001-16,000$ & 1 & $5001-6000$ \\
\hline $81-90$ & 2 & $19,001-20,000$ & - & - \\
\hline $100+$ & 4 & $2001-17,000$ & 2 & $2001-11,000$ \\
\hline
\end{tabular}

*Empty cells for both assistantships/fellowships and supplemental funds are not shown

respondents offering assistantships/ fellowships varied greatly thereafter, although the maximum value was consistently in the mid-teens to $\$ 20,000$.

In addition to funding full assistantships/fellowships, private funds were also used to supplement existing assistantship/fellowships by one-quarter of the respondents. As with fully-funded assistantships, the largest number of respondents offered up to 10 supplemental awards annually, and the number of institutions offering in excess of 10 supplemental awards per year varies greatly. However, inconsistent with the full assistantships, the maximum value of supplemental awards varied from $\$ 6000$ to $\$ 11,000$.

As Table 2 indicates, the allocation of private funds, exclusive of assistantships and other financial support, varied widely.
As noted earlier, approximately half of the respondents engaged in development activities. However, relatively few allocated private funds to promote their development activities. The dean's discretionary account, utilized by only 12 percent of respondents, averaged almost $\$ 100,000$, with a maximum of $\$ 200,000$. Relatively few of the respondents made use of publications, donor events, new programs, and award ceremonies. Given the option to choose "other" activities for private resources, these ranged from only $\$ 500$ to $\$ 100,000$. However, when asked to identify the specific activities that respondents considered "other," most individuals were nonresponsive. The two responses reported were academic chairs and student travel.

When asked to identify the development activities in which they

Table 2: Allocation of private support

\begin{tabular}{lccc}
\hline Allocated for & Respondents (\%) & Allocation $(\boldsymbol{M})$ & Range \\
\hline Dean discretionary account (\$) & 12 & 39,333 & $1000-200,000$ \\
Research/travel support for students (\$) & 11 & 14,785 & $500-75,000$ \\
Events for donors (\$) & 8 & 2500 & $1000-5000$ \\
New programs/initiatives (\$) & 5 & 9333 & $1000-25,000$ \\
Award ceremonies (\$) & 5 & 7120 & $500-20,000$ \\
Events for potential donors (\$) & 3 & 2250 & $2000-2500$ \\
Publications (\$) & 3 & 1500 & $1000-2000$ \\
Other (\$) & 12 & 36,833 & $500-100,000$ \\
\hline
\end{tabular}


Table 3: Development activities and their perceived effectiveness

\begin{tabular}{lcc}
\hline Activity & Mean* $^{*}$ SD \\
\hline $\begin{array}{l}\text { Face-to-face cultivation/solicitation/ } \\
\quad \text { stewardship }\end{array}$ & 4.65 & 0.57 \\
$\begin{array}{l}\text { Coordinated approaches w/central } \\
\quad \text { development }\end{array}$ & 3.60 & 1.14 \\
$\begin{array}{l}\text { Stewardship events (dinners, } \\
\quad \text { celebrations, etc) }\end{array}$ & 3.54 & 1.27 \\
Annual letter solicitations & 2.37 & 1.34 \\
Coordinating volunteer activities & 2.17 & 1.33 \\
Phone solicitations (telefund) & 1.92 & 1.11 \\
Other & 4.40 & 1.34 \\
\hline
\end{tabular}

*On a five-point Likert scale. 5=most effective, $1=$ least effective

engaged and the perceived effectiveness of such activities, results also varied considerably. As Table 3 indicates, personal involvement with cultivation and stewardship (and/or solicitations) of prospective donors was viewed as the most effective development activities. The other activities with means over 3.00 (on a fivepoint Likert scale) were coordinated approaches with the central development office on campus and stewardship events. Less personal forms of communication, such as letter and phone solicitation, were not perceived as particularly effective.

Respondents were given the option of "other" in their assessment of development activities, and this was rated more highly than the aforementioned activities. Surprisingly, only seven respondents specified other activities, which included grant proposals, email solicitations, and newsletters.

These results varied little when examined by institution type. The limited size of the sample required collapsing the institutions into two groups based on Carnegie Classification so that t-test could be performed. Doctoral/research university extensive and intensive were collapsed into one group; and master's colleges and universities I, master's colleges and universities II, and baccalaureate colleges were collapsed into the other group. The only significant differences occurred with coordinated approaches with the central development office. Participants at doctoral/research institutions rate this activity as significantly more effective than those at other institutions $(M=3.76, M=2.67$, respectively, $\mathrm{t} 20=2.53, p<0.05)$.

Finally, 29 percent of the respondents planned to engage in development activities in the future. Surprisingly, 32 percent indicated that they had no such plans. Of those who planned to engage in development activities, the vast majority (81 percent) planned to do so sometime in the 2005 calendar year.

\section{Discussion}

This study provides an initial, exploratory look at development practices in graduate schools. As such, it is useful for marking the coordinates of a still-evolving field. The overall results suggest that graduate schools are in a relatively nascent stage of development activity, a characterization supported by several noteworthy findings.

The finding that 32 percent of those surveyed indicated that they had no future plans to engage in development activities is particularly interesting. More would need to be known about the circumstances surrounding decisions to engage or not engage in development activities on a broader scale, including any plans (or lack of plans) for institutional capital campaigns. Decentralized units typically do not pursue capital campaigns in a vacuum disconnected from larger institutional campaigns.

Equally surprising is the finding that half of respondent graduate schools do not engage in any development activities 
whatsoever. Without a clear understanding of the funding arrangements or other considerations that make formal development efforts unnecessary in these instances, it is difficult to judge the implications of this absence of development activity.

Clearly, private support has not been "replacement revenue" in graduate schools at the same rate seen in other units. One of the notable nationwide trends is that private support is doing more and more of the work traditionally done by state appropriations, tuition, and government support. Between 1980 and 2000, for example, the share of college and university operating expenses supported by state tax dollars was cut by 30 percent. ${ }^{22}$ This trend does not yet appear to be a widespread feature of the graduate school funding picture-only 8 percent of respondents indicated that their schools receive in excess of 10 percent of revenues from private sources.

The majority of private support flowing to graduate schools goes to fellowships and assistantships. While there is nothing particularly surprising in this finding, it may help to place fund-raising efforts in perspective, in the sense that graduate schools-unlike their professional school counterparts-possibly do not seek funds for capital projects, endowed faculty support, or other "big ticket" items that help inflate campaign goals. Perhaps the focus on student support in graduate schools, in other words, helps to account for their more modest fund-raising goals.

It is a well-worn axiom in the development world that it takes money to raise money, and this is often said with respect to the professional development officers needed to carry out the cycle of prospect identification, cultivation, solicitation, and stewardship. Not surprisingly, staff size and budget are key factors in the amount of dollars raised by development offices. ${ }^{23}$ It is not altogether uncommon to find mature development operations housing as many as 10 or 15 development staff, including major gifts officers, annual fund personnel, dedicated alumni relations staff, and administrative support. What is striking in the results from this survey is the low number of full-time, dedicated development personnel responsible for these activities. The low incidence of dedicated development professionals is perhaps both cause and consequence of the general lack of focus on development activities among responding graduate schools.

The limited use of advancement boards by graduate school deans seems to be a variation on the theme indicated immediately above: the lack of key personnel to accomplish fund-raising tasks. Advancement board members typically play a critical role in campaign planning, giving, soliciting gifts, and networking. Clearly, this use is not pervasive in graduate schools.

\section{Implications for Practitioners}

As private support comes to occupy a more central position in higher education funding, we can expect profound changes in graduate school development over the next decade or so. Partly because of competition among graduate schools themselves, we might predict that properties of isomorphism will apply, ${ }^{24}$ and thereby accelerate the rate of graduate school development activity. That is, graduate schools may be expected to copy or mimic the best practices (including fund-raising practices) of peer or rival schools that have already achieved legitimacy or experienced success in the realm of private support. Isomorphism is especially acute in fields constituted by relatively small numbers of players 
competing for the same limited pool of human and material resources (students, faculty, and dollars) and social legitimacy. This set of competitive forces, among others, will present ample future opportunities for research into graduate school development activities.

\section{Limitations}

As with any study, there are limitations that must be acknowledged. First, the response rate of 20 percent was somewhat low. This fact may constrain the generalizability of the results. Secondly, not all CGS member institutions have a centralized graduate school. Thus the findings in this study may not be representative of all graduate schools.

\section{Conclusion}

In an era of declining public support, fund raising has become a vital part of institutional efforts to diversify the resource base and secure a greater measure of self-sufficiency. This is equally true of the separate academic units that comprise colleges and universities. Decentralization of development activities continues apace, but little has been reported about how the movement from centralized to decentralized forms of organization plays out at the unit level. The graduate school context is no exception, and its unique challenges (especially those having to do with the lack of a clear constituency) make it a particularly interesting object of investigation. This study attempts to address the dearth of empirical data by establishing a benchmark of current development practices by graduate schools.

\section{References}

1. J. J. Duderstadt and F. W. Womack (2003), The Future of the Public University in America: Beyond the Crossroads, Johns Hopkins University Press, Baltimore.
2. A. E. Kaplan (2004), 2004 Voluntary Support of Education, Council for Aid to Education, New York.

3. Cbronicle of Higher Education (2005, June 7), "Updates on billion-dollar campaigns," retrieved from <http://chronicle.com/daily/2005/06/ 2005060704n.htm>, July 13, 2005.

4. R. R. Lindgren (2002), "Structuring and managing the development office," in M. J. Worth (Ed.), New Strategies for Educational Fund Raising, Praeger, Westport, CT, pp. 269-82.

5. B. A. Loessin (1997), "Linking fundraising and development with planning," in M. W. Peterson, D. D. Dill, and L. A. Mets (Eds.), Planning and Management for a Changing Environment: A Handbook on Redesigning Postsecondary Institutions, Jossey-Bass, San Francisco, pp. 307-18.

6. K. Battillo (1993), "Development by degrees," Currents, 19, 2, 58-62; M. R. Hall (1993), The Dean's Role in Fund Raising, Johns Hopkins University Press, Baltimore; M. K. Murphy (Ed.) (1992), Building Bridges: Fund Raising for Deans, Faculty, and Development Officers, Council for the Advancement and Support of Education, Washington, DC.

7. J. A. Miller (2000), “The modern law dean," Journal of Legal Education, 50, 3, 398-413.

8. L. M. Brown (2001, November 22), "Bottom-line goals," Black Issues in Higher Education, 18, 20, 44-6.

9. R. E. Gordon (1987), “A graduate dean looks at fund raising," panel discussion paper presented at the Annual Meeting of the Council of Graduate Schools, December, Washington, DC, ERIC Document Reproduction Service Number ED 291302.

10. R. M. Rosenzweig (1998), "Graduate education and its patrons," keynote address presented at the Annual Meeting of the Council of Graduate Schools, November, Colorado Springs, CO, ERIC Document Reproduction Service Number ED 302173.

11. Loessin (1997), op. cit.; E. R. Tempel and M. J. Beem (2002), "The state of the profession," in M. J. Worth (Ed.), New Strategies for Educational Fund Raising, Praeger, Westport, CT, pp. 351-61.

12. K. S. Kelly (2002), "The state of fund-raising theory and research," in M. J. Worth (Ed.), Nere Strategies for Educational Fund Raising, Praeger, Westport, CT, p. 41.

13. W. B. Cook and W. F. Lasher (1996), "Toward a theory of fund raising in higher education," Revieze of Higher Education, 20, 1, pp. 33-51.

14. B. E. Brittingham and T. R. Pezzullo (1990), The Campus Green: Fund Raising in Higher Education (ASHE Higher Education Research Report, Vol. 19, No. 1), Jossey-Bass, San Francisco; G. L. Cascione (2003), Philanthropists in Higher Education: Institutional, Biographical, and Religious Motivations for Giving, RoutledgeFalmer, New York.

15. Loessin (1997), op. cit.

16. Hall (1993), op. cit. 
17. Kelly (2002), op. cit.

18. Lindgren (2002), op. cit.

19. J. B. LaPidus (2001), "Graduate education and research," in P. G. Altbach, P. J. Gumport, and D. B. Johnstone (Eds.), In Defense of American Higher Education, Johns Hopkins University Press, Baltimore, pp. 249-76.

20. B. R. Clark (1998), Creating Entrepreneurial Universities: Organizational Patbways of Transformation (Issues in Higher Education, Vol. 12), Pergamon Press, Oxford.

21. D. Bok (2003), Universities in the Marketplace: The
Commercialization of Higher Education, Princeton

University Press, Princeton, NJ; Hall (1993), op. cit.;

D. L. Kirp (2003), Shakespeare, Einstein, and the Bottom Line: The Marketing of Higher Education, Harvard University Press, Cambridge, MA.

22. Kirp (2003), op. cit.

23. Kelly (2002), op. cit.

24. P. J. DiMaggio and W. W. Powell (1983), "The iron cage revisited: Institutional isomorphism and collective rationality in organizational fields, American Sociological Review, 48, 2, 147-60. 